Вісник ЛНУ імені Тараса Шевченка № 7 (330), 2019

UDC 398; 801.8 (791.43.001.33)

doi : 10.12958/2227-2844-2019-7(330)-86-96

Yuhan N. L.,

Doctor of Philology, Associate Professor,

Assistant Professor of the Preparatory Department

of Taras Shevchenko National University of Kyiv,

Kyiv, Ukraine

ugann12@gmail.com

https://orcid.org/0000-0001-6845-6731

\title{
INFORMATION AND COMMUNICATION TECHNOLOGIES OF TEACHING RUSSIAN LITERATURE TO STUDENTS- FOREIGNERS IN THE HIGHER EDUCATION PRACTICE
}

Systemic introduction of blended (hybrid) education to the practice of higher education in Ukraine has a high-priority importance today. This is due to the rapid development of information and communication technologies (ICT) and their tremendous influence on the way of life and professional activity of a modern person.

There are many points of view on the definition of the term „,blended education" In our study, as a working definition, we use the definition by American researchers G. Hartmann (Hartmann, 2017) and R. Vois (Vois, 2017). Scientists define blended (hybrid) learning as a common instructional program that integrates interpersonal (face-to-face) and computer-mediated (synchronous, online, or asynchronous, offline) interaction of students and lecturers in a specially organized pedagogical environment with the use of teaching technologies.

Over the last years, a significant number of researchers have attempted to analyze the concept of ,blended (hybrid) education” (K. Bugaychuk, L. Dankevich, O. Danisko, A. Kobisia, I. Knish, N. Kochubei, V. Kukharenko, E. Pyanikh, N. Rashevskaya, V. Fantey, T. Shrol, L. Semenovskaya, I. Vorotnikova, etc.), and also to describe specific models of the implementation of blended education in the university practice of teaching individual academic disciplines (O. Alekseev, O. Byndas, V. Bryhinets, K. Ivanova, N. Hyria, V. Kotkova, R. Nur Akhsan, O. Matviichuk, S. Podlasov, T. Rahayu, A. Shcheglova, D. Sulisworo, etc.).

However, the effectiveness of the blended education use in the methodology of teaching the history of Russian literature in the higher education institutions of Ukraine has not yet been studied. This scientific research is devoted to solving this problem.

Out of many types of ICT that can be used in the course „History of Foreign Literature". we have chosen demonstration programs designed for visual demonstration of educational material (films, video fragments) for the pedagogical experiment. 


\section{Вісник ЛНУ імені Тараса Шевченка № 7 (330), 2019}

In modern literature teaching methodologies, films based on the classics are playing a significant role. However, the corresponding teaching methodology is developed mainly for the secondary school (L. Bazhenova, N. Borisenko, I. Dubrovin, B. Lanin, L. Lanina, V. Sitnikova, V. Sobkin, E. Sokolova, S. Stepanova and others).

A few works of scientists are devoted to the consideration of this problem in the university practice. Thus, A. Fedorov analyzes the influence of media classes on the development of students' critical thinking in pedagogical universities (Федоров, 2007); A. Pustovalov examines the problem of using English-language films in practical Foreign Literature classes (Пустовалов, 2012); E. Yashchenko studies the special aspects of the technology students' perception of literary works on the screen (Ященко, 2016); E. Khalpukova explores adaptations and how they can be used for the development of students' speaking skills in a foreign audience (Хальпукова, 2013).

The scientific works about the implementation of the visualization potential of classics in the literature studies are mainly descriptive in nature: scientists analyze the aspects of the literary work and adaptation comparisons (K. Ignatov (Игнатов, 2002), L. Sergeeva (Сергеева, 2019), N. Khilko (Хилько, 2005)), the film is considered as a mean to solve the problems with understanding the literary text (T. Ryzhkova (Рыжкова, 2012), R. Barsam, D. Monahan (Barsam, Monahan, 2012), O. Kindinová (Kindinová, 2012), J. Monaco (Monaco, 2000)). The effectiveness of classics adaptations usage for university lectures for Ukrainian and foreign students has not yet become the subject of scientific research.

Besides, there are no scientific works in which the effectiveness of using the demonstration computer programs in the practice of university teaching of the history of Russian literature in blended (hybrid) learning is studied in comparison with traditional (full-time) training in modern pedagogical science.

The purpose of this article is to study the effectiveness of the use of demonstration computer programs (films, video fragments) in the history course of Russian literature in the universities of Ukraine.

To achieve this goal, we are solving two interrelated tasks:

1. Comparing the results of the training and the opinions of students about the forms of education received in groups with traditional classes and blended (hybrid) education;

2. Studying the effectiveness of classes (lectures and practical exercises) using the adaptations of the Russian classics by Soviet, Russian and foreign directors.

The following methods of research were used to achieve the aim and meet the objectives: questionnaire surveys and testing of students during the pedagogical experiment with further quantitative and qualitative processing of the data, written and oral responses; monitoring the educational activities of students and their success.

Visual interpretations of literary works were actively used at the Faculty of Foreign Languages of Luhansk Taras Shevchenko National University 2011 
-2014 , at the faculty of Ukrainian philology of the same university in 2013 2014, as well as at the social and humanitarian faculty of the Pryazovskyi State Technical University in 2017 - 2018 in the courses „The History of Russian Literature of the 19th Century”, „History of Foreign Literature of the 19th Century" (including Russian literature), „The History of Western European Literature of the 19th Century" (partially Russian literature).

In this course of Literature History we use screen adaptations of literary classical works, we compare Soviet, Russian and foreign films during 7 lectures:

1. „Eugene Onegin” by Alexander Pushkin. Soviet artistic film opera staged in 1958 by the director R. Tikhomirov based on the opera of the same name by Pyotr Tchaikovsky. „Onegin” is a 1999 British-American film directed by Martha Fiennes.

2. „War and Peace” by Leo Tolstoy. The epic film of the famous Soviet film director S. Bondarchuk (1965 - 1966). A film directed by K. Vidor, released on screens in 1956. A 1972 screen version of the famous novel in Britain directed by J. Davis. Mini-series based on the novel directed by Dornhelm in 2007.

3. „Anna Karenina” by Leo Tolstoy. Three adaptations of Soviet and Russian production: a large-scale feature film directed by A. Zarkhi (1967), a talented screen version of S. Soloviev (2009), a modern interpretation of K. Shakhnazarov (2017). Numerous foreign adaptations: the American film (1997); melodrama directed by J. Wright (2012); mini-series based on the novel of the same name directed by K. Duge (2013), Great Britain.

4. „Crime and Punishment” by Fyodor Dostoevsky. A Soviet film, shot in 1969 by director L. Kulidzhanov and Russian eight-episode television film D. Svetozarova (2007). English television series based on the novel directed by J. Jarroll (2002).

5. „The Karamazov Brothers” by Fyodor Dostoevsky. A screen version of the USSR period (1968) directed by I. Pyriev and a Russian version (2009) directed by J. Moroz. Among the screen versions of the world, the most interesting are „Brothers Karamazov”, 1967 (USA, Canada, Iran), director T. Zarindast, „Karamazov”, 2008, (Czech Republic), director P. Zelenka, „Brothers Karamazov”, 2008 (USA), „Karadaglar”, 2010, the series based on the novel by the director O. Terjan (Turkey), the series „The Karamazov Brothers", 2013 (Japan).

6. „Idiot” by Fyodor Dostoevsky. In the USSR and Russia was made into a film by I. Pyriev (1958), R. Kachanov (2001), V. Bortko (2003). Among the many adaptations of the Idiot abroad, we draw attention to the Japanese version by A. Kurosawa (1951), the English television series by A. Bridges (1966) and the Indian version by M. Kaula (1991), A. Waida's film „Nastasya” (Poland), 1994) on the lecture.

7. „Three Sisters” by Anton Chekhov. In Russia, the first screen version was the film „The Three Sisters” by S. Samsonov, it was shot in 1964. Thirty years later, in 1994, S. Soloviev presented his film version of the play. Abroad 
versions by Seidelman, (USA, 2005) and by V. Bruni-Tedeschi (France, 2015) are interesting.

This course was attended by 245 foreign students and 50 Ukrainian second-year students of the specialty „Russian and English languages and foreign literature" at Luhansk Taras Shevchenko National University throughout 3 years (2011 - 2014 academic years). Also, it was attended by 11 Ukrainian second-year students of the specialty „Translation (Russian and Ukrainian)" for 1 year (2013 - 2014 academic year) and by 52 full-time second-year students of the same specialty at Pryazovskyi State Technical University in 2017 - 2018.

3 groups of Ukrainian and foreign students (20 people in each group) were selected for the experiment. Foreign students arrived in Ukraine from Turkmenistan.

Before preparing for the classes, we collected visual material (downloaded films from different websites and YouTube), made up the film library. Then we prepared video clips (up to 15 minutes) to work with students, as well as questions, assignments for analyzing and discussing the visual material presented, control mini-tests to check the received knowledge.

The pedagogical experiment was conducted in 7 sessions ( 3 lectures and 4 practical classes).

In groups No 1 and 2, traditional lectures were read, and on-campus practical sessions were conducted without the use of ICT technologies. In groups No 3 and 4, video fragments were shown, then they were discussed in the group together with the lecturer. At the same time, in group 3, video materials were shown on a large screen, and in group 4, visualizations of works of art were shown on computers (laptops, tablets, smartphones), in other words, each student saw a video fragment on his screen. In group number 5 , the work with video materials took place outside the audience (remotely). The material was worked through by correspondence with the lecturer via e-mail (individual work) or using Skype in video conference mode (collaborative work). In group 6, one part of the work was done in the classroom under the supervision of the lecturer in the process of direct communication between students (internally), and the other part of the work was done in a mediated virtual environment (remotely). Thus, blended (hybrid) education was provided to group number 6 .

After each class, the students were offered a mini-test through which their knowledge was controlled, also questionnaires and interviews were conducted.

The results of questioning and interviewing showed that the students of groups No 3, 4, and 6 took the experiment positively. The students did not make a single claim or wish. Thus, we can conclude that the traditional (fulltime) form of teaching using ICT and blended education are equally organic for the modern educational process when teaching the history of foreign (Russian) literature in the higher education institutions of Ukraine.

The survey of students of group No 5, who worked remotely with audiovisual sources, allowed to determine the positive and negative aspects of 


\section{Вісник ЛНУ імені Тараса Шевченка № 7 (330), 2019}

this form of education. Working in an indirect virtual environment creates the opportunity for students to determine the time, place, path or pace of learning. From negative points, it was noted that students have little contact with the teacher and the group, there is no direct, lively communication with the audience. A desire was expressed to supplement the distance form of training with traditional studies.

To study the effectiveness of using adaptations in groups of Ukrainian and foreign students traditional lectures were read in the group No 1 (Ukrainian students) and group No 2 (foreign students); group No 3 (Ukrainian students) and group No 4 (foreign students) analyzed screen adaptations of works of art of Soviet and Russian filmmaking; parallels between the Russian classics, its Russian and foreign visualizations were drawn in the group No 5 (Ukrainian students) and group No 6 (foreign students).

Interviewing and questioning were conducted after each of the 7 training sessions among students of the discipline „History of foreign (Russian) literature of the XIX century".

Students of all the six groups were offered a questionnaire in which they could evaluate the training sessions on the following criteria: accessibility, motivation to read the work of art, demonstrativeness, creative approach, and the overall rating of the training session. Each section of the questionnaire was rated on a five-point grading scale.

Students of the groups No 3, 4 and 5 gave the maximum grades for all the criteria, and group No 6 gave the minimal grades. We can conclude that Ukrainian and foreign students find traditional lessons to be less interesting than the lessons where visualizations are used. Also, the training sessions, where a literary text is compared to both Russian and foreign adaptation, are less accessible to the perception, understanding and learning for foreign students.

We summarized the results of the questionnaire in accordance with the level of students' comprehension of training sessions materials. For the purposes of discussion, we divided all students into 3 groups: high, medium and low levels of comprehension. Moreover, we introduced additional criteria to study the effectiveness of using the adaptations in the teaching of literature: „activation of cognitive interest" and ,activation of thought processes”. The ,activation of cognitive interest" indicator reveals the extent to which students show interest in the materials which are studied in the lecture, presented with and without visualization. Students evaluated the content of the class, its accessibility, the specifics of the material's design and its presentation, the specifics of the lesson structure, and the motivation strengthening for reading literary classics. When evaluating training sessions on the criterion of „activation of thought processes" students should have paid attention to the richness and diversity of the examples and illustrations presented, the creativity of the approaches and methods of the presentations of material, which were demonstrated during the lectures using video materials, as well as during traditional classes. 
We can see the maximum number of points for all criteria in groups No 3 and No 5. Group No 6 has the minimum value.

The results of the interviewing method can help us make the right conclusions about the effectiveness of the approaches we used. After each class, students were asked how much use or non-use of adaptations was appropriate and effective, how much it increased their interest in literature, and contributed to their personal growth.

In groups of Ukrainian and foreign students No 1 and 2 (in whose groups adaptations of artistic texts were not used), students said that they would be interested in training sessions with parallels between different types of arts. By the way, students of these groups put lower grades for the criterion of „Demonstrativeness" than students of other groups.

In groups No 3 and 4 (where students had classes with fragments from films of Russian production), there were no problems associated with the perception of texts, with the understanding of works of art and their adaptations. Ukrainian students noted that they studied classical works mainly in school or in the family. Many students can easily compare literary plots and adaptations, express their point of view about the acting, the plot, the similarity or differences in the plot of the literary work and the film (the series), and also can conclude whether the director reproduces historical features and everyday realities of the era.

The level of lecture perception received the highest rating for all the criteria by Ukrainian students. When students were asked about the need to draw parallels with foreign films, they thought that this would be interesting, as foreign screen versions are new for them, unlike Soviet and Russian films. This approach would help to expand the outlook and develop aesthetic taste.

The evaluation of training sessions slightly differed in the group of foreign students No 4. Students were interested in comparing Russian classics and its adaptation in masterpieces of Soviet and Russian production. In their opinion, such a technique helped them to better understand the work of art, namely, historical realities, ideological pathos, characters, household details. Besides, such lessons seem to be creative and well-illustrated to these students.

Groups No 5 and 6, where the classics of literature were compared with both Russian and foreign adaptations, gave fundamentally different grades. Ukrainian students perceive such lessons with interest: since they are familiar with these literary works from the school curriculum and they watched Soviet and Russian films, they work with great interest to draw parallels with foreign adaptations. We see the maximum grades for the criteria of „demonstrativeness” and „creativity” for these groups.

We can see a different situation in the group No 6. Foreign students hardly conceive the subjects of Russian literature of the XIX century: they are long, complex, confusing, incomprehensible for them. Students who came to us from Turkmenistan did not study Russian literature at school and they are not familiar with Russian adaptations. The outdated vocabulary of literary classics is complicated and incomprehensible for them. 


\section{Вісник ЛНУ імені Тараса Шевченка № 7 (330), 2019}

In addition, foreigners have some difficulties with analyzing the differences between literary works and their visualizations. When we also make comparisons with foreign films, it overwhelms students' consciousness, which is unprepared to the perception of works of various types of art. They get confused in the plots, author's interpretations, details. These reasons can explain why students of the group No 6 gave low grades for all criteria.

The appeal to the high-quality adaptations of Russian and foreign production of Russian classic literature at the University methodology of foreign literature teaching at the current stage is relevant and promising. Such technologies provide the conditions for the development and self-development of the student's personality, motivate students to read classics and get to know cinematographic masterpieces, thereby opening up opportunities for creative realization of the student.

After evaluating the results of the implementation of training sessions with the usage and analysis of screen versions of Russian classics to Ukrainian and foreign students in the practice of teaching literature, we proved that it is preferable the traditional (full-time) form of teaching using ICT and blended education is preferable and equally organic for the modern educational process when teaching the history of foreign (Russian) literature in the higher education institutions of Ukraine.

For Ukrainian students it is better to compare a literary work with Russian and foreign film versions, and for foreign students it is best to appeal only to Soviet-Russian interpretations of literary masterpieces. This is because of the foreigners' lack of knowledge of the Russian language, the difficulty in reading Russian texts of the 19th century, large enough in volume, as well as the lack of the basic knowledge of Russian history, culture, and filmography. Studying artworks with reference to the famous and high-quality screen versions during the training sessions stimulates cognitive interest, intellectual and creative potential, strengthens the motivation of foreign students to study the Russian language and literature.

At the same time, the experiment revealed that the comparison of Russian and foreign filmography at lessons has the opposite effect in the audience of foreign students. It is difficult for foreign students to perceive a large amount of diverse text and audiovisual information, to make a qualitative comparison of Russian and foreign cinematographic experience because they do not have a linguistic and cultural basis for a multilevel, multidimensional comparative analysis of works of various arts. In general, an appeal to such technologies makes it possible to improve the effectiveness of teaching literary subjects.

The prospect of further research in this direction can be the analysis of the effectiveness of the course on foreign (Russian) literature, based on a comparison of classical literary works and their adaptations, in general, including lectures, practical exercises, and students research work. It is important to compare the quality of literary knowledge obtained by students with the new approaches and with the classical model of a university course. 


\section{Список використаної літератури}

1. Harriman G. What is Blended Learning? E-Learning Resources. URL: http://www.grayharriman.com/blended_learning.htm (retrieved: Sept 25, 2017). 2. Voos R. Blended Learning: What it is and Where it Might Take Us? Sloan-C View. $\quad$ Vols. 2(1), pp. 2-5. URL: http://www.aln.org/publications/view/v2n1/blended1.html. (retrieved: Oct. 5, 2017). 3. Федоров А. В. Развитие медиакомпетентности и критического мышления студентов педагогического вуза. М.: Изд-во МОО ВПП ЮНЕСКО „Информация для всех”, 2007. 616 с. 4. Пустовалов А. В. Кинопостановки на практических занятиях по зарубежной литературе: опыт обращения и использования. URL: http://www.psu.ru/files/docs/personalnyestranitsy-prepodavatelej/pustovalov/filming_in_foreign_literature_2012-04-10.pdf.

5. Ященко Е. Ф. Особенности восприятия литературных произведений на экране у студентов технического вуза. Литература на экране: взгляд психологов, писателей и кинематографистов: материаль Международной научной конференции. 6-7 декабря 2016 г. М.: ПН РАО, 2016. С. 146-150. 6. Хальпукова Е. „Литература на экране” в иностранной аудитории (из опыта преподавания). Славянскія літаратуры $\check{y}$ кантэксие сусветнай: да 900-годдзя Кірыла Тураўскага і 200-годдзя Тараса Шаўчэнкі: матэрыялы ХІ Міжнар. навук. канф., Мінск, 24-26 кастр. 2013 г.: у 2 ч. Мінск, 2013. Ч. 2. С. 398-400. 7. Игнатов К. Ю. Произведения художественной литературы и их экранизация. Материаль Международной конференции студентов, аспирантов и молодых ученых „Ломоносов”. М.: Изд-во Моск. ун-та, 2002. Вып. 7. С. 299-300. 8. Сергеева Л. Е. Опыт использования экранизаций художественных произведений на уроках литературы. URL: https://infourok.ru/opyt_ispolzovaniya_ekranizaciy_hudozhestvennyh_proizvede niy_na_urokah_literatury-136115.html (дата обращения: 15.09.2019). 9. Хилько Н. Ф. Психолого-педагогические особенности аудиовизуального творчества в медиаобразовании. Медиаобразование. 2005. № 6. С. 14-38. 10. Рыжкова Т. В. Экранизация как средство разрешения проблем понимания литературного произведения. URL: http://www.rusnauka.com/5_SWMN_2012/Philologia/1_101056.doc.html (дата обращения: 15.09.2019). 11. Barsam R., Monahan D. Looking at Movies: An Introduction to Film. New York, 2012. 640 p. 12. Kindinová O. Filmová zpracování Anny Karennovè v porovnání s literarární předlohou: magisterská diplomová práce. Olomouci, 2012. 112 p. 13. Monaco J. How to Read a Film: The World of Movies, Media, Multimedia: Language, History, Theory. Oxford University Press, USA, 2000. 672 p.

\section{References}

1. Harriman, G. (2017). What is Blended Learning? E-Learning Resources. Retrieved from: http://www.grayharriman.com/blended_learning.html [in English]. 2. Voos, R. (2017). Blended Learning: What it is and Where it Might Take Us? Sloan-C View, 2(1), 2-5. Retrieved from http://www.aln.org/publications/view/v2n1/blended1.html [in English]. 
3. Fedorov, A. V. (2007). Razvitie mediakompetentnosti i kriticheskogo myshleniya studentov pedagogicheskogo vuza [Development of media competence and critical thinking of students of a pedagogical university]. M.: Izv-o MOO WPP UNESCO «Information for all» [in Russian]. 4. Pustovalov, A. V. (2017). Kinopostanovki na prakticheskih zanyatiyah po zarubezhnoj literature: opyt obrashcheniya i ispol'zovaniya [Film presentations in practical classes on foreign literature: experience in handling and using]. Retrieved from http://www.psu.ru/files/docs/personalnye-stranitsyprepodavatelej/pustovalov/filming_in_foreign_literature_2012-04-10.pdf [in Russian]. 5. Yashchenko, E. F. (2016). Osobennosti vospriyatiya literaturnyh proizvedenij na ekrane $\mathrm{u}$ studentov tekhnicheskogo vuza [Features of the perception of literary works on the screen of students of a technical college]. Literatura na ekrane: vzglyad psihologov, pisatelej $i$ kinematografistov: materialy Mezhdunarodnoj nauchnoj konferencii-Literature on the screen: the view of psychologists, writers and filmmakers: materials of the International Scientific Conference. M. (pp. 146-150) [in Russian]. 6. Khalpukova, E. (2013). „Literatura na ekrane” $\mathrm{v}$ inostrannoj auditorii (iz opyta prepodavaniya) [,Literature on the screen" in a foreign audience (from the experience of teaching)]. Slavic literature in the context of the World: 900-annu. to Cyril Turau and 200-th Shevchenko: XI Materials Intern. Sciences. conf. (part 2). Minsk (pp. 398-400) [in Russian]. 7. Ignatov, K. Yu. (2002). Proizvedeniya hudozhestvennoj literatury $\mathrm{i}$ ih ekranizaciya [Works of fiction and their screen adaptation]. Materialy Mezhdunarodnoj konferencii studentov, aspirantov $i$ molodyh uchenyh „Lomonosov”-Materials of the International Conference of students, graduate students and young scientists "Lomonosov». M. (Issue 7) (pp. 299-300) [in Russian]. 8. Sergeeva L. E. (2014). Opyt ispol'zovaniya ekranizacij hudozhestvennyh proizvedenij na urokah literatury [Experience in the use of adaptations of works of art in literature lessons]. infourok.ru (n. d.). 2014. Retrieved from https://infourok.ru/opyt_ispolzovaniya_ekranizaciy_hudozhestvennyh_proizved eniy_na_urokah_literatury-136115.html [in Russian]. 9. Khilko N. F. (2005). Psihologo-pedagogicheskie osobennosti audiovizual'nogo tvorchestva v mediaobrazovanii [Psychological and Pedagogical Features of Audiovisual Creativity in Media Education]. Mediaobrazovanie - Media Education, 6, 14-38 [in Russian]. 10. Ryzhkova T. V. (2012). Ekranizaciya kak sredstvo razresheniya problem ponimaniya literaturnogo proizvedeniya [Screening as a means of solving the problems of understanding the literary produced]. $\begin{array}{llll}\text { rusnauka.com } & \text { (n.d.). 2012. } & \text { Retrieved }\end{array}$ http://www.rusnauka.com/5_SWMN_2012/Philologia/1_101056.doc.htm [in Russian]. 11. Barsam R. \& Monahan D. (2012). Looking at Movies: An Introduction to Film. New York [in English]. 12. Kindinová O. (2012). Filmová zpracování Anny Karennovè v porovnání s literarární předlohou: magisterská diplomová práce. Olomouci [in Czech]. 13. Monaco J. (2000). How to Read a Film: The World of Movies, Media, Multimedia: Language, History, Theory. Oxford University Press, USA [in English]. 
Юган Н. Л. Інформаційно-комунікаційні технології у практиці викладання російської літератури студентам-іноземцям у закладах вищої освіти

У статті представлений порівняльний аналіз результатів використання інформаційно-комунікаційних технологій у 6 групах (120 осіб) українських студентів та студентів-іноземців, отриманих за допомогою методів анкетування й інтерв'ювання. Оцінюючи результати впровадження в практику викладання літератури у ЗВО України українським та іноземним студентам занять 3 використанням демонстраційних комп'ютерних програм (фільми, відеофрагменти), ми переконалися, що традиційна (очна) форма навчання з використанням IKT та змішане навчання однаково органічні для сучасного навчального процесу; для українських студентів оптимальним $\epsilon$ зіставлення літературного твору з російськими та зарубіжними кіноверсіями, а для іноземних студентів - звернення тільки до радянсько-російських інтерпретацій літературних шедеврів. Пов'язано це 3 недостатнім знанням іноземцями російської мови, складністю прочитання російських текстів XIX ст., досить великих за обсягом, а також з відсутністю базових знань російської історії, культури, фільмографії. Звернення до знаменитих та якісних екранізацій стимулює пізнавальний інтерес, інтелектуальний та творчий потенціал, посилює мотивацію студентівіноземців до вивчення російської мови і літератури. Іноземним студентам складно сприймати велику кількість різнопланової текстової та аудіовізуальної інформації, провести якісне зіставлення російського та зарубіжного кінематографічного досвіду внаслідок несформованої у них лінгвокультурологічної основи для багаторівневого різноаспектного компаративного аналізу творів різних видів мистецтв.

Ключові слова: змішане (гібридне) навчання, інформаційнокомунікаційні технології, іноземні студенти, ефективність навчання.

Юган Н. Л. Информационно-коммуникационные технологии в практике преподавания русской литературы студентаминостранцам в учреждениях высшего образования

В статье представлен сравнительный анализ результатов использования информационно-коммуникационных технологий в 6 группах (120 человек) украинских студентов и студентов-иностранцев, полученных при помощи методов анкетирования и интервьюирования. Оценивая результаты внедрения в практику преподавания литературы в УВО Украины украинским и иностранным студентам занятий с использованием демонстрационных компьютерных программ (фильмы, видеофрагменты), мы убедились, что традиционная (очная) форма обучения с использованием ИКТ и смешанное обучение одинаково органичны для современного учебного процесса; для украинских студентов оптимальным является сопоставление литературного произведения с российскими и зарубежными киноверсиями, а для иностранных студентов - обращение только к 
советско-российским интерпретациям литературных шедевров. Связано это с недостаточным знанием иностранцами русского языка, сложностью прочтения русских текстов XIX в., достаточно больших по объему, а также с отсутствием базовых знаний русской истории, культуры, фильмографии. Обращение к знаменитым и качественным экранизациям стимулирует познавательный интерес, интеллектуальный и творческий потенциал, усиливает мотивацию студентов-иностранцев к изучению русского языка и литературы. Иностранным студентам сложно воспринимать большое количество разноплановой текстовой и аудиовизуальной информации, провести качественное сопоставление российского и зарубежного кинематографического опыта вследствие не сформировавшейся у них лингвокультурологической основы для многоуровневого разноаспектного сравнительного анализа произведений различных видов искусств.

Ключевые слова: смешанное (гибридное) обучение, информационно-коммуникационные технологии, иностранные студенты, эффективность обучения.

Yuhan N. L. Information and communication technologies of teaching Russian literature to students-foreigners in the higher education practice

The article presents a comparative analysis of the results of the use of information and communication technologies in 6 groups (120 people) of Ukrainian and foreign students which was obtained by means of methods of questioning and interviewing. After assessing the results of the introduction into the practice of teaching literature to Ukrainian and foreign students with the use of demonstration computer programs (films, video fragments) we ascertained that the traditional (full-time) form of teaching using ICT and blended education was equally organic for the modern educational process in the higher education institutions of Ukraine; comparison of literary works with Russian and foreign film versions is optimal for Ukrainian students and appeal to the Soviet-Russian interpretations of literary masterpieces only - for foreign students. This is due to foreigners' insufficient competence in the Russian language, the difficulty in reading large enough volume Russian texts of the XIX century as well as lack of basic knowledge of Russian history, culture and filmography. Reference to the famous and high-quality film adaptations at training sessions stimulates cognitive interest, intellectual and creative potential, enhances the motivation of foreign students to study Russian language and literature. It is difficult for foreign students to perceive a large number of diverse textual and audiovisual information, to make a qualitative comparison of Russian and foreign cinematic experience due to their unformed linguistic and cultural basis for multi-level multi-dimensional comparative analysis of works of different types of arts.

Key words: blended (hybrid) education, information and communication technologies, foreign students, learning efficiency.

Стаття надійшла до редакції 01.10.2019 р.

Стаття прийнята до друку 04.10.2019 р.

Рецензент - д. філ. н., проф. Каразін В. П. 